
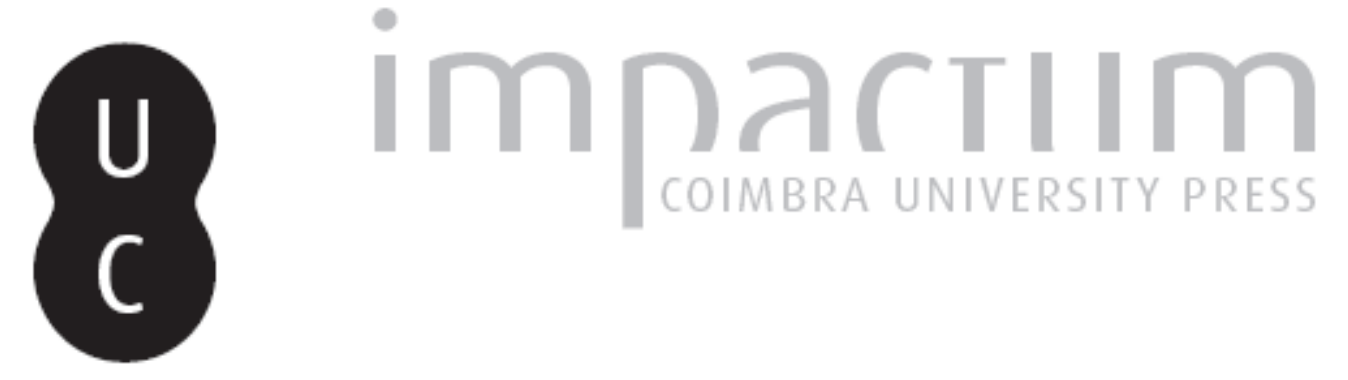

\title{
[Recensão a] Angelo D’Orsi, II Futurismo tra cultura e politica. Reazione o rivoluzione? Con antologia di testi
}
Autor(es):
Gigliucci, Roberto

Publicado por: Imprensa da Universidade de Coimbra

URL

persistente:

URI:http://hdl.handle.net/10316.2/42592

DOI:

DOI:https://doi.org/10.14195/0870-8584_4_21

Accessed : $\quad$ 26-Apr-2023 11:10:29

A navegação consulta e descarregamento dos títulos inseridos nas Bibliotecas Digitais UC Digitalis, UC Pombalina e UC Impactum, pressupõem a aceitação plena e sem reservas dos Termos e Condições de Uso destas Bibliotecas Digitais, disponíveis em https://digitalis.uc.pt/pt-pt/termos.

Conforme exposto nos referidos Termos e Condições de Uso, o descarregamento de títulos de acesso restrito requer uma licença válida de autorização devendo o utilizador aceder ao(s) documento(s) a partir de um endereço de IP da instituição detentora da supramencionada licença.

Ao utilizador é apenas permitido o descarregamento para uso pessoal, pelo que o emprego do(s) título(s) descarregado(s) para outro fim, designadamente comercial, carece de autorização do respetivo autor ou editor da obra.

Na medida em que todas as obras da UC Digitalis se encontram protegidas pelo Código do Direito de Autor e Direitos Conexos e demais legislação aplicável, toda a cópia, parcial ou total, deste documento, nos casos em que é legalmente admitida, deverá conter ou fazer-se acompanhar por este aviso.

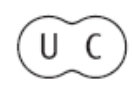




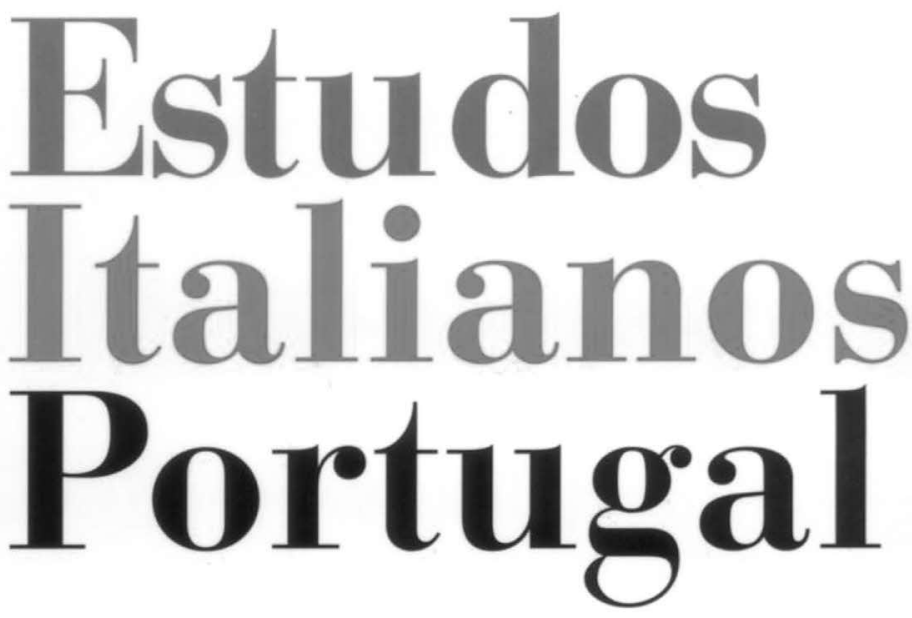

Instituto

Italiano

de Cultura

de Lisboa

Nova Série

$\mathbf{N}^{\mathbf{0}} 4$.

2009 
Angelo D'Orsi, Il Futurismo tra cultura e politica. Reazione o rivoluzione? Con antologia di testi, Roma, Salerno, 2009, pp. 337

A todos aconselho - aos jovens em particular - a leitura do livro de Angelo D'Orsi sobre o Futurismo, porque diz qual é o estado de coisas (ou melhor, qual era), quanto à vanguarda italiana de início de século e à sua precisa contextura política.

Depois de uma introdução em que a hermenêutica gramsciana é oportunamente colocada no centro do discurso, o livro articula-se numa primeira série de capítulos dedicada aos elos que ligaram o Futurismo, no plano histórico, quer ao nacionalismo, quer ao arditismo, quer ao fascismo, e noutra série de capítulos que delineia o percurso do meteórico Partido Futurista Italiano e aprofunda o belicismo futurista, face às diversas situações que se perfilam entre a Guerra da Líbia, a Grande Guerra, o 1919, etc., procurando também compreender as franjas ultra-minoritárias de um Futurismo de esquerda e descrever o crepúsculo do Futurismo, com o regime de Mussolini, ou melhor, o seu triunfo ambiguamente institucional. Segue-se uma cronologia pormenorizada e uma antologia de textos verdadeiramente significativa, sobretudo para quem não é especialista.

$\mathrm{Na}$ verdade, o maior mérito do volume é a clareza que caracteriza não só a forma de exposição adoptada, como também as posições tomadas. D'Orsi, que assim segue, nobremente, os rastos de Bobbio, considera funcional a distinção entre direita e esquerda para compreender a história e a política, sem hesitações ao situar o Futurismo, com abundância de documentação, no campo da cultura direitista. Neste ponto, a clareza é essencial: as operações de uma certa esquerda, empenhada em interpretar o Futurismo, pelo menos na sua forma originária, como um movimento artístico revolucionário, não necessariamente vinculado ao pensamento-acção de direita que estruturou o século XX europeu (ou a sua primeira metade), são tentativas falhadas. O Futurismo é a vanguarda da filosofia/prática da violência, da guerra, do assalto, da virilidade, da penetração e do arrombamento, do não-igualitarismo, da modernidade como 
massacre, da estetização da força como esplendor primitivo dos machos àristoi e, portanto, paradigma de governo das massas. D’Orsi faz bem, ao citar com frequência Mario Morasso e o seu nietzschianismo, que pode não ser bonito, mas é facilmente assimilável. E também faz bem, ao evidenciar o papel central que cabe à exaltação da guerra nas vicissitudes do Futurismo e de Marinetti, desde o Manifesto de Fundação, de 1909, até ao fúnebre, que dá pena, Quarto d'ora di poesia della X Mas de 1944. O flirt com o massacre, que identifica a modernidade, é luxúria futurista até às entranhas. O êxtase repulsivo da chacina e do sangue que conota a cultura do grupo reunido em torno da revista Lacerba, de Florença, e as posições de Marinetti, são unha com carne.

Em suma, a Itália foi a vanguarda do fascismo, ou antes, dos fascismos europeus, e foi a vanguarda da vanguarda, tendo-a inventado com o Futurismo e tendo-a definido, enquanto tal, como destrudo estética e sócio-antropológica. Esta é cultura de direita do século XX. Só que, se Benn, Céline, Pound ou Cioran, pese embora a diversidade dos seus percursos ideológicos e biográficos, foram grandes escritores, Marinetti e quantos o rodearam foram medíocres, sem sombra de dúvida, pelo que diz respeito aos resultados da sua obra artística. D'Orsi, no campo estético, não assume frontalmente um juízo de valor, e, portanto, é a mim que cabem estas afirmações finais, em tom conclusivo.

Quero dizer que, quanto ao Futurismo, também em momento de aniversário e celebrações é necessário conservar clareza de vistas e disponibilidade de espírito para avaliar criticamente. Se a Itália teve, historicamente (e talvez ainda o tenha) o genial privilégio de propor a vanguarda política do pior, não é caso para dourar a pílula. E reconheçamos serenamente que é sempre possível melhorar. ROBERTO GIGLIUCCI. Trad. de RITA MARNOTO 